\title{
Hypopharyngeal Cancer Pathologic Primary Tumor TNM Finding v6
}

National Cancer Institute

\section{Source}

National Cancer Institute. Hypopharyngeal Cancer Pathologic Primary Tumor TNM

Finding v6. NCI Thesaurus. Code C64445.

A pathologic finding about one or more characteristics of hypopharyngeal cancer,

following the rules of the TNM AJCC v6 classification system as they pertain to staging of the primary tumor. 